\title{
Effect of Maximal Anaerobic Loading on Lower Extremity Proprioceptive Sense in Soccer Players
}

\author{
Mehmet Göktepe $^{1}$, Ergün Çakır², Meral Miyaç Göktepe ${ }^{3}$, Ömer Şenel ${ }^{4}$ \\ ${ }^{1}$ Balıkesir Universty, Physical Education and Sports, Turkey \\ ${ }^{2}$ Kafkas Universty, Physical Education and Sports, Turkey \\ ${ }^{3}$ Gazi University, Institute of Health Science, Turkey \\ ${ }^{3}$ Gazi University, Faculty of Sports Sciences, Turkey \\ Correspondence: Mehmet Göktepe, Balıkesir Universty, Turkey. E-mail: mgoktepe06@gmail.com
}

$\begin{aligned} & \text { Received: November 14, } 2018 \quad \text { Accepted: December 3, } 2018 \quad \text { Online Published: January 28, } 2019 \\ & \text { doi:10.11114/jets.v7i2.3768 }\end{aligned}$ URL: https://doi.org/10.11114/jets.v7i2.3768

\begin{abstract}
This study was carried out to determine the effect of lower extremity muscle fatigue on proprioceptive sense in soccer players. 26 male soccer players who play licensed soccer in the amateur soccer teams of the Ağr province and who was not injured in the past year (Age 20,03 $\pm 3,38$, weight 65,69 $\pm 10,66$, height 176,61 $\pm 8,72$ ) participated in the study voluntarily. The lactic acid concentration of the participants at rest and their proprioceptive sense measurements were determined by standardized methods and materials. Then, Wingate test was applied to the participants. The lactic acid concentration and proprioceptive sense measurements were repeated at the end of the test. The analysis of the collected data was carried out through the SPSS 22 program. Shapiro-Wilks test was conducted for normality distribution. Independent-Samples t-test was carried out in the comparison of test and control groups and Paired-Samples t-Test was utilized in the comparison of differences between pretest and posttest means. It was concluded that lower extremity fatigue in soccer players has a negative effect on lower extremity proprioceptive sense $(\mathrm{p}<0.05)$.
\end{abstract}

Keywords: soccer, fatigue, proprioceptive sense, lactic acid, heart rate

\section{Introduction}

The aim of the study is to determine the effect of fatigue in soccer players on alt extremity proprioceptive sense.

Therefore, this study is important in terms of revealing the need for studying the effect of muscle fatigue on proprioceptive sense in soccer players with all its aspects and for the development of programs to prevent sports injuries.

Hypothesis of the study: Fatigue in football players, lower extremity proprioceptive sensation is the negative effect.

Literature Review: Fatigue occurs due to the combination of many consecutive factors and reduces athletic success and performance with the impairment of contraction force or strength (Kirkendall, 1990; Sharon and Denise, 2003; Billat, 2001; Olaru and Öztürk, 1994). In terms of athletes, fatigue is defined as "sensation of weakness, slowness and, sometimes, pain in muscles" (Billat, 2001). Muscular fatigue is defined as the insufficiency that occurs in the production or maintenance of a certain power through muscle contraction (Günay and Cicioğlu, 2001). Muscle fatigue is a risk factor for muscular and skeletal diseases. One of the negative effects of muscle fatigue is the fact that it causes decrease in performance (Ferraz et. al, 2012; Bompa, 1994). In sport branches, the level of fatigue affects competition results. Moreover, loss of competitions by a narrow margin at the elite level makes the study of the causes of fatigue and its toleration very important. Muscle fatigue studies are being carried out to minimize these undesired situations (Allison and Fujiwara, 2002; Klimek, 2010). Muscular fatigue is known to change the proprioceptive system, the central proprioception process and, at the same time, the power production capacity (Şimşek and Ertan, 2011). Proprioception is the position phenomenon of the joint and extremity provided by the neural stimulus that occurs through joints and receptors in tissues covering these joints (Hughes and Rochester, 2008; Hindle et. al, 2012). Proprioceptive sense plays a significant role in the provision and maintenance of joint stability (Erkmen et. al, 2007). The concept of proprioception is becoming more important in the etiology, diagnosis and treatment of sports injuries or joint diseases. It has been indicated that proprioceptive deficiency facilitates injuries, proprioception in joints deteriorate after injuries and proprioceptive rehabilitation decreases the frequency of injuries or accelerates the treatment process (Evans et. al, 2002). 


\section{Method}

26 male soccer players who play licensed soccer in the amateur soccer teams of the Ağr province (Age 20,03 $\pm 3,38$, weight $65,69 \pm 10,66$, height $176,61 \pm 8,72$ ) was included in the study. The content of the study was explained to every soccer player who agreed to participate in the study with all its details. Before the tests, all soccer players filled and signed the health questionnaire used in the determination of their health condition and the informed consent form that stated they participated in the study voluntarily. Weights and heights of the participants were measured respectively before fatigue. Blood samples were taken to determine lactic acid concentration, a 5-minute warm-up run was made and after their adaptation to the proprioceptive sense platform was ensured, proprioceptive sense measurements were conducted. Then, Wingate test was applied to the test subjects. After Wingate test, blood samples were taken to determine the lactic acid concentration that occurred due to fatigue and the research was finalized after the proprioceptive sense posttest measurements. This study was conducted at the Physiology Laboratory of Ağrı İbrahim Çeçen University, School of Physical Education and Sport.

Height and Body Weight Measurements:

The heights of the test subjects were measured by a height meter with a $0.01 \mathrm{~m}$ degree of accuracy (SECA, Germany) and body weight measurements were taken by an electronic scale with a $0.1 \mathrm{~kg}$ degree of accuracy (SECA, Germany) (Köklü et. al, 2009).

Body Mass Index (BMI):

BMI was calculated through the division of the body weights' kg value by the square of the heights' meter measurement $\left(\mathrm{kg} / \mathrm{m}^{2}\right)$ (Moran and McGlynn. 1996; Norris et. al, 2005; Taylor et. al 1998).

Fatigue protocol (Anaerobic Wingate Test):

Wingate Anaerobic Power Test was conducted to create fatigue in the soccer players in the test group. The ergometer of a monark brand 834E model bicycle with scales and a computer mechanism connected to the bicycle were used for the test. Before the test, a standard warm-up was carried out by the test group at the bicycle ergometer which consisted of a 6-minute exercise at 140-150 rate/min heart rate (HR) and 2-minute stretching exercises (Gökbel et. al, 1993). Saddle length of the bicycle was adjustedfor every test subject and 7,5\% gr load per each $\mathrm{kg}$ their body weight was placed in the bicycle's saddle. The test subject who was subjected to a 30 -second pedaled as fast as he could without getting upfrom the saddle throughout the test. When the test subject reached maximum speed, the load was removed and the test was started. The test subject was verbally motivated throughout the test and particularly in the last 10-15 seconds.

Determination of lactic acid concentration:

Blood samples were taken to determine the pretest and posttest lactate (lactic acid) concentration (La) of the test subjects). Blood samples for La were taken from earlobes and were immediately measured inYSI Sport 1500 LA analyzer (Yellow Spring Inst. USA) electroenzymatically with no processing. The analyzer was calibrated every test day in line with the manufacturing firm's guidance (Alemdaroğlu et. al, 2008).

Proprioceptive Sense Measurements:

Proprioceptive sense measurements were taken by using an isokinetic dynamometer of Pro-Kin, Technology, Dalmine, Italy brand $\left(20 \mathrm{~Hz}\right.$ sampling rate, sensitivity $0.1^{\circ}$, product type:PK252). Proprioceptive Sense Test was carried out by the selection of Multiaxial Proprioceptive Assessment Module with a proven validity and reliability (Tessalina et. al, 2016; Wang et. al, 2011) and the pressure level of the stabilometer was adjusted to the difficulty degree of 5 (out of 50) for this test (Göktepe et. al, 2015). The test subjects were asked to keep their hands on the handles of the device throughout the test. The test was completed by rotating the platform 5 times clockwise within 60 seconds by following the round route on the screen (Göktepe et. al, 2015; Song et. al, 2013; Göktepe et. al, 2015).

Data Analysis:

Statistical assessment was made through the SPSS 22.0 (SPSS Inc., Chicago, IL, USA) program. Collected data is presented as means and standard deviation. Shapiro-Wilks test was conducted for normality distribution. As the data exhibited normal distribution, parametric tests were chosen. Paired-Samples t-Test was utilized in the comparison of differences between the pretest and posttest means of the soccer players. The results were assessed in the 95\% confidence interval and $\mathrm{p}<0.05$ was considered significant.

\section{Results}

In Table 1, age, body weight, height, body mass index and sports age of the participant soccer players are $20,03 \pm 3,38$ years, $65,69 \pm 10,66 \mathrm{~kg}, 176,61 \pm 8,72 \mathrm{~cm}, 20,97 \pm 2,52 \mathrm{~kg} / \mathrm{m} 2$ and $9,31 \pm 3,35$ years respectively. 
Table 1. Physical characteristics of participant soccer players

\begin{tabular}{cccccc}
\hline $\mathbf{N}$ & $\begin{array}{c}\text { Age }(\text { year }) \\
(\text { Mean } \pm \text { SD) }\end{array}$ & $\begin{array}{c}\text { Body Weight }(\mathbf{k g}) \\
(\text { Mean } \pm \text { SD) }\end{array}$ & $\begin{array}{c}\text { Height }(\mathbf{c m}) \\
(\text { Mean } \pm \text { SD) }\end{array}$ & $\begin{array}{c}\text { BMI(kg/m2) } \\
(\text { Mean } \pm \text { SD) }\end{array}$ & $\begin{array}{c}\text { Sports Age } \\
\text { year }) \\
(\text { Mean } \pm \text { SD) }\end{array}$ \\
\hline 26 & $20,03 \pm 3,38$ & $65,69 \pm 10,66$ & $176,61 \pm 8,72$ & $20,97 \pm 2,52$ & $9,31 \pm 3,35$ \\
\hline
\end{tabular}

Table 2. Descriptive statistic of soccer players' Wingate test scores

\begin{tabular}{lll}
\hline \multicolumn{2}{c}{ Test: (N:26) } & (Mean \pm SD) \\
\hline & PP $[W]$ & $704,90 \pm 238,46$ \\
\cline { 2 - 3 } & AP $[W]$ & $533,34 \pm 165,08$ \\
\cline { 2 - 3 } & MP $[W]$ & $332,75 \pm 94,51$ \\
\cline { 2 - 3 } & FI & $52,79 \pm 12,03$ \\
\hline
\end{tabular}

PP: Peak Power, AP: Avg. Power, MP: Min. Power, FI: Fatigue Index

The descriptive statistic of soccer players' Wingate test scores in the test group were found $\mathrm{PP}(\mathrm{w}) 704,90 \pm 238,46, \mathrm{AP}(\mathrm{w})$ $533,34 \pm 165,08, \mathrm{MP}(\mathrm{w}) 332,75 \pm 94,51$, FI 52,79 $\pm 12,03$ in Table 2.

Table 3. Dependent t-Test Results Conducted to Test the Significance of the Difference Between the Pretest and Posttest of Soccer Players' Heart Rate, Lactate and Proprioceptive Sense Scores

\begin{tabular}{|c|c|c|c|c|c|c|c|c|}
\hline & & & $\mathbf{N}$ & $\mathbf{X}$ & SS & SD & $\mathbf{t}$ & $\mathbf{p}$ \\
\hline \multirow{6}{*}{ 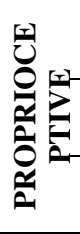 } & \multirow{2}{*}{ SI $\left(^{\circ}\right)$} & Pretest & 26 & 0,95 & 0,55 & 31 & \multirow{2}{*}{6,47} & \multirow{2}{*}{$0,00 *$} \\
\hline & & Posttest & 26 & 1,45 & 0,59 & 31 & & \\
\hline & \multirow{2}{*}{ AFV (kg) } & Pretest & 26 & 1,38 & 0,62 & 31 & \multirow{2}{*}{1,21} & \multirow{2}{*}{0,23} \\
\hline & & Posttest & 26 & 1,64 & 1,07 & 31 & & \\
\hline & \multirow{2}{*}{ ATE (\%) } & Pretest & 26 & 28,69 & 10,31 & 31 & \multirow{2}{*}{7,75} & \multirow{2}{*}{$0,00 *$} \\
\hline & & Posttest & 26 & 36,72 & 12,81 & 31 & & \\
\hline & \multirow{2}{*}{$\begin{array}{c}\mathbf{L A} \\
(\mathbf{m m o l} / \mathbf{L}-1)\end{array}$} & Pretest & 26 & 1,36 & 0,15 & 31 & \multirow{2}{*}{50,51} & \multirow{2}{*}{0,00 * } \\
\hline & & Posttest & 26 & 4,62 & 0,31 & 31 & & \\
\hline
\end{tabular}

*(p < 0.05) SI: Stability indicator, AFV: Average force variance, ATE: Average tracking error.

Considering the pretest and posttest dependent $t$ test results of the participant soccer players in Table 3, no statistically significant difference was found for Proprioceptive Sense (AFV) values ( $>>0,05)$. A significant difference was detected for LA, Proprioceptive Sense (SI) and (ATE) values $(\mathrm{p}<0.05)$. After the fatigue protocol applied to soccer players, a significant difference was found in favor of LA and Proprioceptive sense values.

\section{Discussion}

Proprioceptive abilities have a very important effect on athletic performance. Performance improvement of athletes and decrease in injuries during sports activities depend on proprioceptive abilities as the majority of sports activities is implemented at high speed (Laskowski et. al, 2000). Even though the most frequently assessed parameter of proprioception is the sense of joint position, there is no standard measurement method. There are different measurement methods for proprioceptive sense. In this study, isokinetic dynamometer measurement method was used (Laskowski et. al, 2000; Dover and Powers, 2003; Voight et. al, 1996).

After the fatigue protocol was applied to soccer players, a regression was detected in lower extremity proprioceptive sense parameters.

Skinner et. al (1986) evaluated the pre and post protocol position sense on the knee they applied the fatigue protocol to and found a difference that indicated a clear decrease in joint position sense in pre and post fatigue measurements. Miura et. al (2004) conducted a study in which they examined the effect of local and general fatigue on knee proprioception. In this study, local fatigue occurred as maximum isokinetic knee flexion and extension at isokinetic dynamometer and general fatigue occurred as a 5-minute run on a treadmill. No change was observed in knee proprioception scores after local fatigue but values dropped after general fatigue. After a bicycle exercise Roberts et. al (2003) carried out on a Borg scale prepared for the perception of fatigue which the test subjects did until oxygen perception reached a stable level, a regression occurred in knee joint proprioception values after the exercise. Johnston et. al (1998) found that motor control performance decreased significantly in post-fatigue values created by using an isokinetic dynamometer. These results comply with this study's results.

Myers et. al (1999) created fatigue in the shoulder by implementing an internal and external rotation exercise with an isokinetic dynamometer, made a comparison by taking the pre and post-exercise active position sense and found a clear difference between pre and post-fatigue values. In a study carried out by Carpenter et. al (1998), the effect of muscle fatigue on knee proprioception was examined in 20 subjects with no shoulder problems. Proprioception was tested first when the subject were at rest and then after they exercised on an isokinetic test machine until they were fatigued and it 
was finally reported that fatigue cause a decrease in the proprioceptive sense. Zabihhosseinian et. al (2015) believe that upper extremity proprioception may deteriorate after fatigue. As deteriorations occurred in upper extremity proprioceptive sense according to the results of these studies, they partially support the results of this study.

Ageberg et. al (2004) created fatigue in patients with chronic anterior cruciate ligament injury who did not have an operation by using a submaximal bicycle exercise with short resting periods. They assessed pre and post-exercise conditions by stability test and found no difference between the patient group and the control group in terms of exercise effect. Brown and Bowyer (2002) investigated the effect of fatigue in university students on ankle stability and proprioception. In measurements taken after the exercise, ankle stabilization was found to be increasing despite muscle fatigue. This was attributed to the fact that moderate activities stimulated neuromuscular neurons and increased the perception power of joint positions. As a result of this study, it can be said that submaximal loading affects the sense of proprioception positively. In a study carried out by Miura et. al, (2004), no significant variability resulting in a decrease at the expected level was observed in the proprioception assessment based on joint position sense perceptions in the closed kinetic systems of the test subjects. The results of the studies conducted by Brown and Bowyer (2002), and Miura et. al, (2004) support the results we obtained in our study. With exercise, viscoelastic properties of muscle improve, they get better oxygen and vasodilatation occurs as a result of the increase in body heat. These physiological changes improve the receptor functions in joint and neuromuscular structures (Astrand et. al, 1986). For instance, when body heat increases, pyrexia threshold value of skin receptors falls and, thus, the sensitivity of the sense of touch increases. In a similar vein, response of muscles to central orders changes positively with exercise. As a result, stimulus thresholds of mechanoreceptors in muscles fall. All these changes are reported to positively increase the sense of joint position (Astrand et. al, 1986; Bouet and Gahery, 2000; Hazneci et. al, 2005; Miura et. al, 2004).

Waddington et. al, (1999) carried out wobble board training on rugby players for 5 weeks and observed development in both ankle and knee joint position sense of the athletes after exercise. Friden et. al (2001) stated that neuromuscular, proprioceptive and field-specific exercise programs may develop knee joint proprioception. In a study carried out by Aydın et. al (2002), ankle balance and proprioception of 20 healthy control and 20 young female gymnasts and gymnastic exercises were found to have a positive effect on the perception of the ankle position. Panics et. al (2008) conducted a 16-week proprioceptive exercise method on female handball players and found that proprioceptive exercise developed the knee joint proprioception considerably and the difference was significant compared to the control group. Ashton et. al (2001) discussed whether exercise develops proprioception and could not reach a clear conclusion. In a study carried out by Tsang et. al (2005), adults who practice Tai Chi regularly were found to have stronger knee muscle strength and better balance scores than the control group.

In the light of the conducted studies, proprioception is believed to be attainable and practicable (Barrack et. al, 1984). According to numerous studies in the literature, people who exercise more regulary have a better balance and proprioceptive sense than those who do not exercise (Aydin et. al, 2002; Barrack et. al, 1984; Barrack et. al, 1983). Proprioceptive mechanism plays a role in the stabilization of joints and provides the interaction between capsuloligamentous structures and dynamic muscular force (Sharma, 1999; South and George, 2007).

Acute and mild warm-up exercises and stretches (Bartlett and Warren, 2002) strengthens the neuromuscular protective mechanisms of reflexes by increasing the mechanoreceptor sensitivity of long-term mild and tiring exercises, i.e. they affect the balance and joint position sense positively. However, movements acutely made at fatigue level impairs muscle spindle and GTO activity and affects joint position sense negatively. As a result, athletes are exposed to injuries (Bartlett and Warren, 2002). Acute and chronic period results are partially similar. However, acute period tiring activities are believed to have a bigger negative effect on proprioceptive sense.

\section{Conclusion}

It was concluded that lower extremity fatigue negatively affects lower extremity proprioceptive sense in soccer players. In other words, proprioception and fatigue are negatively correlated.

\section{Acknowledgements}

I would like to thank to Ömer Şenel, who is in charge of this research.

\section{References}

Ageberg, E., \& Roberts, D. (2004). Holmström E, Fridén T. The effect of short-duration sub-maximal cycling on balance in single-limb stance in patients with anterior cruciate ligament injury: a cross-sectional study. $B M C$ Musculoskeletal Disorders; 5, 1-1. https://doi.org/10.1186/1471-2474-5-44

Alemdaroğlu, U., Arslan, E., Karakoç, B., \& Köklü, Y. (2008). Farklı seviyedeki liglerde oynayan takımların altyapısında mücadele eden genç futbolcularda supramaksimal bacak egzersizi yanıtlarının karşılaştıılması, SPORMETRE Beden Eğitimi ve Spor Bilimleri Dergisi; VI, 21-25. https://doi.org/10.1501/Sporm_0000000127

Allison, G., \& Fujiwara, T. (2002). The relationship between EMG median frequency and low frequency band amplitude changes at different levels of muscle capacity, Clinical Biomechanics; 17, 464-469. https://doi.org/10.1016/S0268-0033(02)00033-5 
Ashton-Miller, J. A., Wojtys, E. M., Huston, L. J., \& Fry-Welch, D. (2001). Can proprioception really be improved by exercises?. Knee surgery, Sports Traumatology, Arthroscopy; 9(3), 128-136.

https://doi.org/10.1007/s001670100208

Astrand, P. O., \& Rodahl, K. (1986). Textbook of Work Physiology. New York: Mc Graw Hill international Editions.

Aydin, T., Yildiz, Y., Yildiz, C., Atesalp, S., \& Kalyon, T. A. (2002). Proprioception of the ankle: a comparison between female teenaged gymnasts and controls. Foot \& Ankle International, 23(2), $123-129$. https://doi.org/10.1177/107110070202300208

Barrack, R., Skinner, H., \& Brunet, M. (1983). Joint laxity and proprioception in the knee. Physician. Sports Med; 11, 130-135.

Barrack, R., Skinner, H., \& Brunet, M. (1984). Joint kinesthesia in the highly trained knee. J Sports Med., 24, 18-20.

Bartlett, M. J., \& Warren, P. J. (2002). Effect of warming up on knee proprioception before sporting activity. British Journal of Sports Medicine; 36, 132-134. https://doi.org/10.1136/bjsm.36.2.132

Billat, L.V. (2001). Interval training for performance: a scientific and empirical practice, Sports Med., 31(1), 13-31. https://doi.org/10.2165/00007256-200131010-00002

Bompa, T. O. (1994). Theory and methodology of training: the key to athletic performance. Kendall Hunt Publishing Company.

Bouet V, \& Gahery Y. (2000). Muscular exercise improves knee position sense in humans. Neurosci Lett., 289(2), 143-146. https://doi.org/10.1016/S0304-3940(00)01297-0

Brown, J. P., \& Bowyer, G. W. (2002). Effects of Fatigue on Ankle Stability and Proprioception in University Sportspeople, Br J Sport Med; 36(4), 310- 312. https://doi.org/10.1136/bjsm.36.4.310

Carpenter, J. E., Blasier, R. B., \& Pellizzon, G. G. (1998). The effects of muscle fatigue on shoulder joint position sense. Am J Sports Med; 26, 262-265. https://doi.org/10.1177/03635465980260021701

Dover, G. C., \& Powers, M. E. (2003). Reliability of joint position sense and force-reproduction measures during internal and eksternal rotation of the shoulder. J Athl Train; 38(4), 304-310.

Erkmen, N., Suveren, S., \& Göktepe, S. (2007). Yazıcığlu K. Farklı branşlardaki sporcuların denge performanslarının karşılaştırılması, Spormetre Beden Eğitimi ve Spor Bilimleri Dergisi, (3), 115-122.

Evans, R. K., Knight, K. L., Draper, D. O., \& Parcell, A. C. (2002). Effects of warm-up before eccentric exercise on direct markers of muscle damage. Medicine \& Science in Sports \& Exercise; 1892-1899. https://doi.org/10.1097/00005768-200212000-00006

Ferraz, R., Tillaar, R. V. D., \& Marques, M. C. (2012). The effect of fatigue on kicking velocity in soccer players. Journal of Human Kinetics; 35, 97-107. https://doi.org/10.2478/v10078-012-0083-8

Friden, T., Roberts, D., Ageberg, E., Walden, M., \& Zatterstrom, R. (2001). Review of knee proprioception and the relation to extremity function after an anterior cruciate ligament rupture. J Otrhopedy Sports Physical Therapi; 31 , 567-576. https://doi.org/10.2519/jospt.2001.31.10.567

Gamelin, F. X., Berthoin, S., \& Bosquet, L. (2006). Validity of the polar S810 heart rate monitor to measure intervals at rest. Med. Sci. Sports Exerc, 38(5), 887. https://doi.org/10.1249/01.mss.0000218135.79476.9c

Gökbel, H., Çalışkan, S., Özbay, Y., \& Bediz, C. Ş. (1993). Farklı yüklerle yapılan wingate testlerinde güç değerleri, Hacettepe Üniversitesi Spor Bilimleri Dergisi, 4(4), 10-16.

Göktepe, M., Şenel, Ö., \& Özkan, A. (2015). Bazı raket sporlarıyla uğraşan sporcuların reaksiyon zamanları ve el kavrama kuvvetleri ile denge ve proprioseptif duyularının ilişkisi. Sstb International Refereed Academic Journal of Sports, Health \& Medical Sciences; 17.

Günay, M., \& Cicioğlu, İ. (2001). Spor fizyolojisi. Ankara. Gazi Kitabevi.

Hazneci, B., Yildiz, Y., Sekir, U., Aydin, T., \& Kalyon, T. A. (2005). Efficacy of isokinetic exercise on joint position sense and muscle strength in patellofemoral pain syndrome. Am J Phys Med Rehabil.; 84(7), 521. https://doi.org/10.1097/01.phm.0000167682.58210.a7

Hindle, K. B., Whitcomb, T. J., Briggs, W. O., \& Hong, J. (2012). Proprioceptive neuromuscular facilitation (PNF): 1ts mechanisms and effects on range of motion and muscular function. Journal of Human Kinetics; 31, $105-113$. https://doi.org/10.2478/v10078-012-0011-y

Hughes, T., \& Rochester, P. (2008). The Effects of Proprioceptive exercise and taping on proprioception in subjects with functional ankle instability, Physical Therapy in Sport; 9, 136-147. https://doi.org/10.1016/j.ptsp.2008.06.003

Johnston, R. B., Howard, M. E., Cawley, P. W., \& Losse, G. M. (1998). Effect of lower extremity muscular fatigue on motor control performance. Medicine and Science in Sports and Exercise; 30(12), 1703-1707. https://doi.org/10.1097/00005768-199812000-00008

Kirkendall, D. T. (1990). Mechanisms of peripheral fatique. Med. Sci. Sports Exerc, 22(4), $444-449$. https://doi.org/10.1249/00005768-199008000-00004

Klimek, A. T. (2010). Physiological background of muscular pain during skiing and delayed muscle soreness after skiing. Journal of Human Kinetics; 23, 55-61. https://doi.org/10.2478/v10078-010-0007-4 
Köklü, Y., Özkan, A., Alemdaroğlu, U., \& Ersöz, G. (2009). Genç futbolcuların bazı fiziksel uygunluk ve somatotip özelliklerinin oynadıkları mevkilere göre karşılaştırılması. Spormetre Beden Eğitimi ve Spor Bilimleri Dergisi; VII(2), 61-68. https://doi.org/10.1501/Sporm_0000000151

Laskowski, E. R., Aney, K. N., \& Smith, J. (2000). Proprioception. Phys Med and Rehab Clinics of North America; 11(2), 323-368. https://doi.org/10.1016/S1047-9651(18)30132-3

Miura, K., Ishibashi, Y., Tsuda, E., Okamura, Y., Otsuka, H., \& Toh, S. (2004). The effect of local and general fatigue on knee proprioception. The Journal of Arthroscopic \& Related Surgery; 20(4), 414-418. https://doi.org/10.1016/j.arthro.2004.01.007

Moran, G. T., \& Mc Glynn, G. (1996). Dynamics of training and conditioning. 2nd Edition. USA. WBC/McGraw-Hill.

Myers, J. B., Guskiewicz, K. M., Schneider, R. A., \& Prentice, W. E. (1999). Proprioception and neuromuscular control of the shoulder after muscle fatigue. Journal of athletic training; 34(4), 362.

Norris, J. M., Langefeld, C. D., Scherzinger, A. L., Rich, S. S., Bookman, E., Beck, S. R., ... Wagenknecht, L.E. (2005). Quantitative trait loci for abdominal fat and BMI in hispanic-americans and African-Americans: The IRAS family study. International Journal of Obesity; 29, 67-77. https://doi.org/10.1038/sj.ijo.0802793

Olaru, M. A., \& Öztürk, F. (1994). Sportif antrenman teori ve medoloji. Çukurova Üniversitesi Basımevi.

Panics, G., Tallay, A., Pavlik, A., \& Berkes, I. (2008). Effect of proprioception training on knee joint position sense in female team handball players. British Journal of Sports Medicine; 42(6), 472-476. https://doi.org/10.1136/bjsm.2008.046516

Roberts, D., Ageberg, E., Andersson. G., \& Friden, T. (2003). Effects of short-term cycling on knee joint proprioception in healthy young persons. The American Journal of Sports Medicine; 31(6), 990-994. https://doi.org/10.1177/03635465030310064001

Sharma, L. (1999). Proprioceptive impairment in knee osteoarthritis. Rheum Dis Clin. North Am,; 25(2), 299-314. https://doi.org/10.1016/S0889-857X(05)70069-7

Sharon, A. P., \& Denise, L. S. (2003). Exercise physiology for health, fitness and performance. 2th ed, San Francisco. Benjamin Cummings Publishing.

Şimşek, D., \& Ertan, H. (2011). Postural kontrol ve spor: kassal yorgunluk ve postural kontrol ilişkisi, Spormetre Beden Eğitimi ve Spor Bilimleri Dergisi; IX (4), 119-124.

Skinner, H. B., Wyatt, M. P., Hodgdon, J. A., Conard, D. W., \& Barrack, R. L. (1986). Effect of fatigue on joint position sense of the knee. Journal of Orthopaedic Research, 4(1), 112-118. https://doi.org/10.1002/jor.1100040115

Song, J., N1, C., \& Zhang, K. (2013). A comparative study on proprioception between lower limbs of unaffected side of hemiplegic patients after stroke and lower limbs of normal person. Chinese Journal of Rehabilitation Medicine; $1(9)$.

South, M., \& George, K. P. (2007). The effect of peroneal muscle fatigue on ankle joint position sense. Physical Therapy in Sport; 8, 82-87. https://doi.org/10.1016/j.ptsp.2006.12.001

Taylor, R. W., Keil, D., Gold, E. J., Williams, S. M., \& Goulding, A. (1998). Body mass index, waist girth and waist-to-hip ratio as indexes of total and regional adiposity in woman: Evalution using receiver operating characteristics curves, The American Journal of Clinical Nutrition; 67, 4 4-49.

Tessalina, S. G., Herrington, R. J., Taylor, R. N., Sundblad, K., Maslennikov, V. V., \& Orgeval, J. J. (2016). Lead isotopic systematics of massive sulphide deposits in the urals: Applications for geodynamic setting and metal sources. Ore Geology Reviews; 72, 22-36. https://doi.org/10.1016/j.oregeorev.2015.06.016

Tsang, W. W., \& Hui-Chan, C. W. (2005). Comparison of muscle torque, balance and confidence in older tai chi and healthy adult. American College of Sports Med; 280-289.

Voight, M. L., Hardin, J. A., Blackburn, T. A., \& Caner, G. C. (1996). The effects of muscle fatigue on the relationship of arm dominance to shoulder proprioception. $J$ Orthop Sports Phys Ther; 23, 348-352. https://doi.org/10.2519/jospt.1996.23.6.348

Waddington, G., Adams, R., \& Jones, A. (1999). Wobble board (ankle disc) training effects on the discrimination of inversion movements, Aust J Physiother; 45(2), 95-101. https://doi.org/10.1016/S0004-9514(14)60341-X

Wang, S., Yang, J., \& Zhu, Y. (2011). Reliability and validity of static balance measures in hemiplegic patients using balance feedback training equipment. Chinese Journal of Rehabilitation Medicine; 11, 13

Zabihhosseinian, M., Holmes, M. W., \& Murphy, B. (2015). Neck muscle fatigue alters upper limb proprioception. Exp Brain Res., 233(5), 1663-1675. https://doi.org/10.1007/s00221-015-4240-x

\section{Copyrights}

Copyright for this article is retained by the author(s), with first publication rights granted to the journal.

This is an open-access article distributed under the terms and conditions of the Creative Commons Attribution license which permits unrestricted use, distribution, and reproduction in any medium, provided the original work is properly cited. 